\title{
BUSINESS ECO SYSTEM AND MICRO, SMALL AND MEDIUM ENTERPRISES (MSMES) PERFORMANCE IN NIGERIA
}

\author{
Moruff Sanjo OLADIMEJI ${ }^{1}$, Benneth Uchenna EZE ${ }^{2}$, Kazeem Adeyinka AKANNI ${ }^{3}$ \\ Olabisi Onabanjo University
}

\begin{abstract}
Firms are adopting collaborative network, which allow group of enterprises to enhance their performance and competitiveness. This study examines the effect of business ecosystem on MSMEs financial and non financial performance. The study employed survey research design, through the administration of structured questionnaires to 400 chief executives of MSMEs in Lagos, Anambra and Kano. The research instrument was validated by some academics and practitioners. A pilot study was conducted to ascertain the reliability of the instrument, by distributing the questionnaire to chief executives of 10 MSMEs twice within an interval of 14 days and the correlation of the first and the second study gave a Cronbach alpha of 0.84, which indicated that the instrument is highly reliable. Hypotheses were formulated and ordinary least square was employed to estimate the model with the aid of STATA version 14. Findings revealed that business eco system have positive and significant effect on MSMEs financial and non-financial performance. Therefore, it is recommended that MSMEs should consider their business eco system towards the enhancement of their financial and non financial performance
\end{abstract}

\section{KEY WORDS}

Business Eco System, MSMES, Financial and Non-Financial Performance

\section{JEL CLASSIFICATION}

L25, L22, L26

\section{INTRODUCTION}

Business ecosystems are ways of describing the operating environment and information framework that enterprises and investors are actively involved in. In the second half of the $20^{\text {th }}$ century, business challenges, as well as business network pervasiveness evolved due to the development of social, economic, political, and technological systems (Iansiti \& Levien, 2004). The business ecosystem includes; suppliers, distributors, customers, competitors, government agencies, among others, it is an economic community supported by a foundation of interacting organizations and individuals, that is, the organisms of the business world (Moore, 1993). 
${ }^{1}$ Corresponding address: Moruff Sanjo Oladimeji (Ph.D.) Department of Business Administration, Faculty of Administration \&Management Sciences, Olabisi Onabanjo University, Ago - Iwoye, Ogun State, Nigeria Email: sanjolanre4life@yahoo.com +2348023567721

2 Corresponding address: Benneth Uchenna EZE' Department of Business Administration, Faculty of Management and Social Sciences, Hallmark University, Ijebu-Itele, Ogun State, Nigeria ${ }^{3}$ Corresponding address: Kazeem Adeyinka AKANNI, Department of Business Administration, Faculty of Administration \&Management Sciences, Olabisi Onabanjo University, Ago - Iwoye, Ogun State, Nigeria

Scholars (Littunen, 2000; Baghbadorani \& Harandi, 2012; Ekpe \& Norsiah, 2015; Pratono \& Mahmood, 2016; Oladimeji, 2017) have established relationship between business eco system and firm performance. However, most of the study used only financial performance measure and considering the shortcomings of financial performance measures, Kaplan and Norton (1996) suggested the balanced scorecard, which entails the combination of financial and non-financial measures. Financial performance measures include; profit, revenue, earnings per share, return on investment, return on equity. Watt and Zimmerman (1986) opine that one major demerit of financial performance measures is that; it can be manipulated by top executives, since bonuses are usually tied to financial performance.

According to Ibrahim \& Lloyd (2011) non-financial measures include; customer satisfaction, workforce development, on time delivery, product quality, productivity, employee satisfaction, market share, among others. While financial performance measure focuses on the past record of the firm, non-financial performance measure considers the future of the firm. High performance on non-financial performance measures is positively related with future financial performance Ibrahim \& Lloyd (2011).

In addressing the research gap, this study therefore sought to empirically examine the effect of business ecosystem (measured by competitive intelligence, social network, innovation and collaboration) on MSMEs financial and non-financial performance (measured by revenue, market share and employees satisfaction) in Nigeria.

\section{LITERATURE REVIEW}

\subsection{Conceptual Review}

\subsubsection{Business Ecosystem}

Business ecosystem was introduced by Moore (1993), which he refer to as an economic community supported by a foundation of interacting organizations and individuals, which is the organisms of the business world. This economic community produces goods and services of value to customers, who are themselves members of the ecosystem. The members of the business ecosystem also include; suppliers, lead producers, competitors, and other stakeholders. Over time, they co-evolve their capabilities and roles, and tend to align themselves with the directions set by one or more central firms.

Business challenges, as well as business network pervasiveness, have evolved due to the development of social, economic, political, and technological systems (Iansiti \& Levien, 2004). Lewin \& Regine (1999) opine that a business ecosystem is a network of enterprises each occupying a place on its own landscape of possibilities, and each landscape being united to many others (competitors, collaborators, and investors). Due to this interconnectedness, changes in the landscape of one enterprise cause changes in the landscapes of other members of the business ecosystem. 
The concept of business ecosystem is increasingly gaining concern among stakeholders thus, encouraging the social network of collaboration, innovation and competitive intelligence among key market players, such as; suppliers, distributors, competitors, consumers, producers, government agencies and so on, towards sustainable survival and enterprises performance. The elements of business ecosystem employed for this study includes: Competitive intelligence, social network, innovation and collaboration.

\subsubsection{Innovation}

Innovation is the introduction of new product, process or market, Schumpeter (1934) identify the following five types of innovations that define business act: Product innovation (the introduction of a new good or service, that is, one with which consumers are not yet familiar or of an higher quality, process innovation (the introduction of a new method of production or service delivery), business model innovation (the opening of a new market for the branch or producer; the discovery of a new source of supply of raw materials of manufactured goods, irrespective of whether this source already exist), mergers and divestments (The formulation and implementation of strategy, like the creation of a monopoly position or the breaking up of a monopoly position). Innovation is also categorized into four kinds: Launch of a new product or a new brand of already known product, application of new methods of production or sales of a product, opening of a new market (the market for which a branch of the industry was not yet represented), acquiring of new sources of supply of raw material or semi-finished goods (Amit, Glosten \& Muller, 1993; Hobday, 1995).

\subsubsection{Competitive Intelligence}

Competitive intelligence (CI) is the action of defining, gathering, analyzing, and distributing intelligence about products, customers, competitors, and any aspect of the environment needed to support executives and managers in strategic decision making for enterprises (Erickson \& Rothberg, 2009). CI means understanding and learning what is happening in the world of one's business, towards enhancing competitiveness. It means learning as much as possible, as soon as possible, about one's industry in general, one's competitors, or one's countries. It is the practice or process of ensuring that the strengths of your own business or product outweighs those of other businesses, in order to make your business or product more competitive.

Erickson and Rothberg (2009) explored level of competitive intelligence activity in firms in business oriented and consumer-oriented industries and concluded that the level of competitive intelligence is higher in consumer industries than business-to-business. Barnea (2010) noted that competitive intelligence $(\mathrm{CI})$ is the gathering of publicly available information about an enterprise's competitors and the use of that information to gain a business advantage.

The goals of competitive intelligence include discerning potential business risks and opportunities and enabling faster reaction to competitors' actions and events. Enterprises use competitive intelligence to compare themselves to other firms (competitive benchmarking), to discover opportunities and identify risks in their markets and to weight their tactics on market response towards making informed decisions. Most firms today want to know what their competitors are doing and how the industry is changing, however, information gathered allows firms to understand their strengths and weaknesses. One of the major activities involved in corporate competitive intelligence is the use of key performance indicators (KPI) (Gilad, 2008).

\subsubsection{Social Network}

According to Portes (1998) social network is the connection among individuals, enterprises, institution and the norms and trust that arise from that relationship. It focuses on the ability of group members (enterprises) to receive economic benefits from social network, and increase access to resources that influence their shared or collective interactions, as they relate with other enterprises (players). Portes (1998) criticism of social network is that individual enterprise is often ignored 
although; this may not be the case in practice because many different types of relationship exist. Social network focuses on both intra-enterprises; and inter-enterprise, in terms of formal and informal relationship (Kim \& Sherraden, 2014)

\subsubsection{Collaboration}

Collaboration refers to a purposeful relationship in which all parties (players) strategically choose to associate and cooperate in order to achieve shared or overlapping objectives. Hessman (2013) noted that enterprises are usually afraid that someone else might steal their ideas and take them to the market, that competitors might profit from what they have done, but in order to push technologies and processes to the next level, one need to reach out to other enterprises, even your competitors. This presupposes that firms should collaborate with other players in the business ecosystem.

\subsubsection{Micro, Small and Medium Enterprise (MSMEs)}

The micro, small and medium enterprises (MSMEs) yard stick varies across countries. Eze, Woremegbe \& Kolawole (2016) opine that in defining MSMEs, reference is usually made to some quantifiable measures such as number of paid employees, capital investment, the annual turnover (sales), asset value, profit margin and market share or a combination of two or more of these measures. In categorizing organizations as micro, small, medium scale enterprises (MSMEs) so many criteria have been employed across nation and across agencies. Some of these criteria include:

The European Commission EC (2013) defined MSMEs largely in terms of the number of employees as follows:

- Enterprises with 1 to 9 employees- micro enterprises;

- 10 to 99 employees-small enterprises

- 100 - 499 employees -medium enterprises.

National Council on Industry of Nigeria (2001) defined Micro, Small and Medium Enterprises (MSMEs) as follows:

- Micro/Cottage Industry: Industry with asset base of not more than 1.5 million excluding cost of land, but including working capital and a staff strength of not more than 10.

- Small Scale Industry: Industry with asset base of more than $\$ 1.5$ million but not in excess of $\$ 50$ million excluding cost of land, but including working capital and/or a staff strength from 11 to 100.

- Medium Scale Industry: Industry with asset base of more than $\$ 50$ million, but not in excess of 200 million excluding cost of land but including working capital and/or a staff strength from 101 to 300.

Table 2.1: Classification adopted by National Policy on MSMEs

\begin{tabular}{|l|l|l|l|}
\hline & SIZE CATEGORY & EMPLOYMENT & $\begin{array}{l}\text { ASSET ( } \\
\text { and buildings) }\end{array}$ \\
\hline 1. & Micro Enterprise & Less than 10 & Less than 5 \\
\hline 2. & Small Enterprises & $10-49$ & 5 - less than 50 \\
\hline 3. & Medium Enterprises & $50-199$ & 50 - less than 500 \\
\hline
\end{tabular}

Source: National Policy on MSMEs (2011)

Similarly, drawing from MSMEs statistical analysis published by National bureau of statistics report (NBS) (2016), the number of unregistered MSMEs in the country is 36,407, 416. While 
approximately 1,481,457 or 4.07 per cent are registered micro, small and medium enterprises in the country.

\subsection{Theoretical Review}

There are various theories that aid the exploration of the effect of business eco system on firms' performance. However, this study adapts social network theory.

\section{Social Network Theory}

Social networks theory was originally developed by Bourdiew (1985), it emphasis was on group member's ability to access actual or potential resources, such as information, from the social networks. Social networks theory Portes (1998) states that social networks is the ability of group members to receive economic benefits from social network, and gain access to resources that influence their social interactions, as they relate with other group members.

Social network theory postulates that social groups can exist as personal and direct social ties that either link individuals who share values and belief or impersonal, formal, and instrumental social links, which can benefit the players. Kim and Sherraden (2014) pointed to the nature of networks and the effect of network size on interaction; and examined the likelihood of interaction in loosely knit networks rather than groups.

Social network theory focuses on both intra-organization; and inter-organization, in terms of formal and informal relationship. Intra-organizational networks often contain simple levels of analysis, specifically, in micro enterprises with less branches or semi-autonomous units. In these cases, research is often conducted at a workgroup level and enterprises level, focusing on the interplay between the structures. However, Rather than tracing interpersonal interactions, macro-level analyses generally trace the outcomes of interactions, such as economic, markets, distribution, supply or other resource transfer interactions over a large population of players (Portes, 1998).

\subsection{Empirical review}

David (2007), used exploratory method to review the dynamic capabilities on the nature of micro foundations for sustainable enterprise performance, findings established that the framework advanced can help scholars understand the foundations of long-run enterprise performance while helping entrepreneurs and managers mark-out relevant strategic considerations and the priorities they must adopt to enhance enterprise performance and escape the zero profit tendency associated with operating in markets open to global competition. Barney, Pan, Lu, and Huang (2009) examined the effect of leveraging digital business ecosystems for enterprise agility, the study contributes to a networked perspective of IT-enabled enterprise and provides practitioners with a comprehensive and empirically-supported framework for the development and subsequent leverage of a digital business ecosystem.

Baghbadorani and Harandi (2012) adopted a biological term to develops a new way of looking at relationship between enterprises, in which they are seen as interconnected and interdependent members of 'ecosystems' that co-evolve and share a common fate. They uncover the dynamics of business ecosystems and propose a conceptual model that can lead to better understanding of the concept, as well as paving the way for future study of its various components. Ekpe and Norsiah (2015), employed cross sectional design on social networks and women micro enterprise performance; the study shows that entrepreneurs and micro enterprises do not only need loans and skill acquisition training but also social network to provide access to information and other resources such as professional advice and avenue for customers.

Ebitu, Basil and Ufot (2016) empirically appraise Nigeria's micro, small and medium enterprises (MSMEs): Growth, challenges and prospects. The results shows that setbacks to MSMEs include; limited financing, lack of action plan to deal with eventualities, lack of managerial and 
marketing skill, and lack of research appreciation and technical expertise. The study concluded that entrepreneurship and micro enterprise is very crucial to the economic growth and development of Nigeria. As such, it was recommended that government policies should support the establishment, nurturing and growth of MSMEs by curtailing or banning importation of certain products, training of young entrepreneurs, establishment of centers for entrepreneurial development and promoting entrepreneurial spirit through the provision of conducive entrepreneurial environment, funding and empowerment programmes.

Oladimeji (2017) examine the relationship between entrepreneurship skill, strategic thinking and business ecosystem in Nigerian businesses using survey method and finds that entrepreneurship skill and strategic thinking have a significant relationship with business ecosystem in Nigeria. Paula and Luís (2017) found in their study that collaborative business ecosystem influences financial and non financial performance Indicators of firms. Balogun, Yusuf, and Oloniniyi (2017) conducted a study on the effects of social network, an indicator of business ecosystem on production output of maize farmers in Kwara State, Nigeria using survey research method. Results showed that labour contribution and decision making index of farmers are the only significant variables affecting productivity.

\section{Figurel Conceptual Framework}

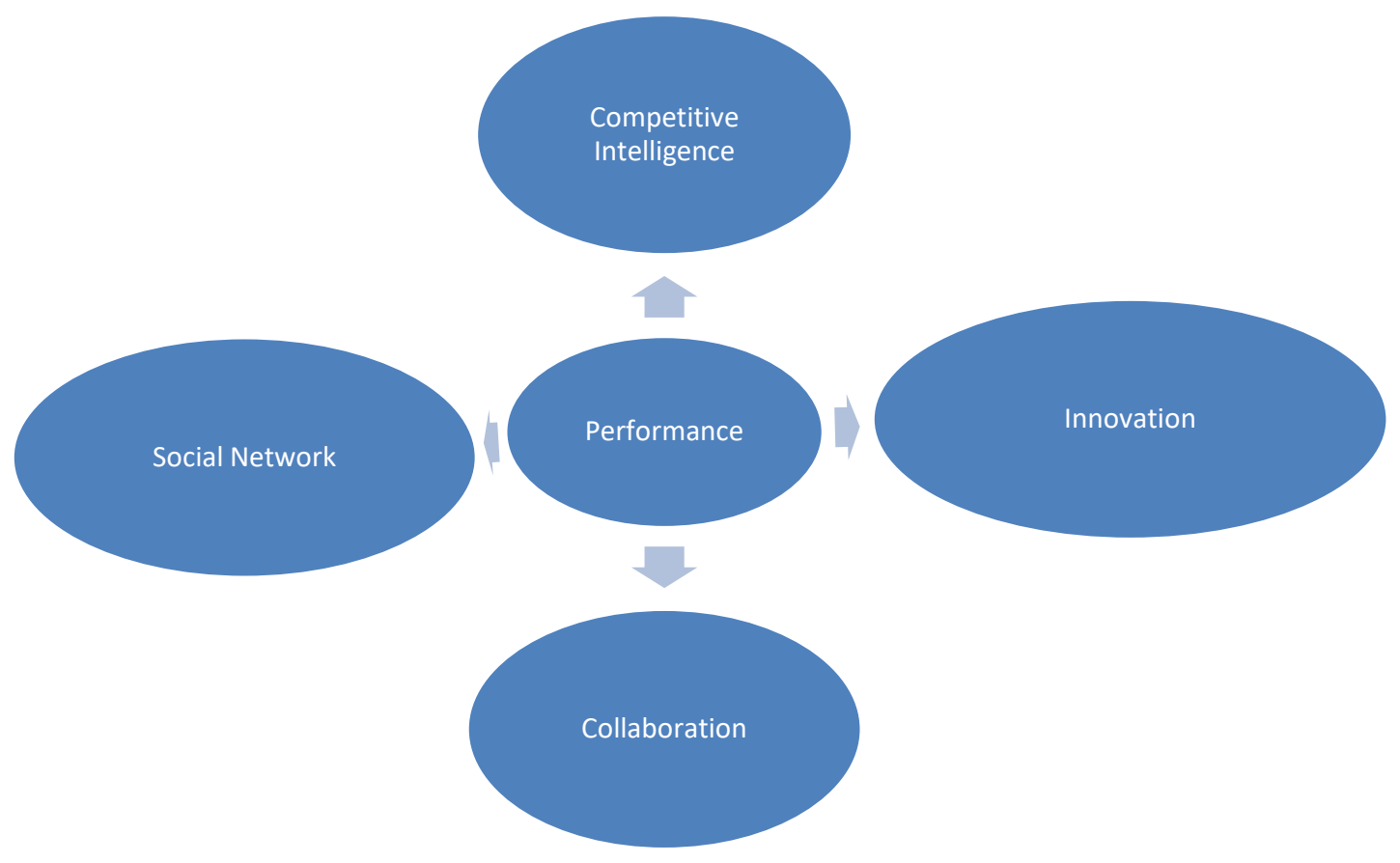

Source: Authors 2018

The conceptual framework suggests that Competitive intelligence, social network, innovation and collaboration will enhance MSMEs performance.

\section{RESEARCH SAMPLE AND METHODOLOGY}

Survey research design was adopted, through the use of questionnaire to collect primary data from chief executives of MSMEs in Lagos, Kano and Anambra. Creswell (2014) posits that survey method is used when a researcher aim at gathering information from a given sample or population and to examine the interactions of relevant variables in the study. The population of the study consists of 37,067,416 MSMEs in Nigeria (NBS, 2016). 
Taro Yamane (1967) sample size determination formula was adopted to arrive at a sample size of 400 (399.99). The study employed purposive sampling technique to select 400 MSMEs in Lagos, Kano and Anambra. The reason for sourcing information from chief executives of MSMEs in Lagos, Kano and Anambra was because they are among the top ten states with the highest number of MSMEs in Nigeria.

Primary data was collected through the administration of structured questionnaires to chief executives of MSMEs in Lagos, Kano and Anambra. A 4-point likert scale with responses structured as strongly agree (4), agree (3), disagree (2), strongly disagree (1) was stated on the instrument so that the respondents can indicate their levels of agreement or disagreement with regards to each of the statements.

The validity of the instrument was tested using content validity index (CVI), through the assessment of four academics and four chief executives of MSMEs, the assessors rated the instrument on a twopoint scale (relevant and not relevant) which gave a value of 0.9054 , which indicated that the instrument was highly valid. A pilot study was conducted through test re-test method to ascertain the extent of reliability of the instrument, the questionnaire was administered twice within an interval of fourteen days, the result of the first and second test was correlated, which gave a Cronbach alpha of 0.84 , which indicated that the instrument is reliable.

In attaining the research objective, which is to empirically examine the effect of business ecosystem (measured by competitive intelligence, social network, innovation and collaboration) on MSMEs financial and non-financial performance (measured by revenue, market share and employees satisfaction) in Nigeria, five research hypotheses were formulated.

\section{Research Hypotheses}

$\mathrm{Ho}_{1}$ : Competitive intelligence does not significantly affect MSMEs performance in Nigeria.

$\mathrm{Ho}_{2}$ : Social network does not significantly affect MSMEs performance in Nigeria.

$\mathrm{Ho}_{3}$ : Innovation does not significantly affect MSMEs performance in Nigeria.

$\mathrm{Ho}_{4}$ : Collaboration does not significantly affect MSMEs performance in Nigeria.

$\mathrm{Ho}_{5}$ : Business ecosystem components (Competitive intelligence, social network, innovation and collaboration) do not have a combine significant effect on MSMEs performance in Nigeria.

\section{Model Specification}

The theory underpinning the model for this study is the social network theory.

$P E R F=f(C I, S N, I N V, C O L)$

$\mathrm{PERF}=\beta_{0}+\beta_{1} C I+\beta_{2} S N{ }_{i}+\bar{\beta}_{3} I N V_{i}+\beta_{4} C O L+{ }_{i} \mu_{i}-----(i i)$

Where:

PERF represents Performance

$\beta_{0}$ is the constant term

$\beta_{1}, \beta_{2}, \beta_{3}, \beta_{4}$ are the coefficient of the estimator.

$\beta_{1}, \beta_{2}, \beta_{3}, \beta_{4}>0$

CI, SN,INV and COL are Competitive intelligence, social network, innovation and collaboration respectively.

$\mu_{i}$ is the error term

The apriori expectation is such that business ecosystem components (Competitive intelligence, social network, innovation and collaboration) are expected to positively affect MSMEs performance in Nigeria; hence, the parameters of business ecosystem (Competitive intelligence, social network, innovation and collaboration) should have a positive sign. 


\section{sciendo}

400 copies of questionnaires were administered to the targeted respondents, 328 copies were returned and useable. This gave a response rate of $82 \%$, which is sufficient for this study. The data analysis was guided by the objective and hypothesis of the study as well as the instrument employed for data collection. STATA 14 was employed for the analysis; this was obtained by using ordinary least square to estimate the regression model.

\section{RESULTS AND DISCUSSION}

Tables 4.1 Micro, Small and Medium Enterprises (MSMEs) by State

\begin{tabular}{|c|c|c|c|}
\hline STATE & MICRO & SMALL & MEDIUM \\
\hline ABIA & 904,721 & 1,769 & 40 \\
\hline AKWA-IBOM & $1,319,607$ & 898 & 195 \\
\hline $\begin{array}{l}\text { ANAMBRA } \\
\text { (Targeted state) }\end{array}$ & $1,223,395$ & 1,620 & 117 \\
\hline BAUCHI & 944,503 & 2,039 & 27 \\
\hline BAYELSA & 541,332 & 354 & 72 \\
\hline BENUE & $1,479,145$ & 1,146 & 22 \\
\hline CROSS RIVER & 921,256 & 1,126 & 168 \\
\hline DELTA & $1,536,158$ & 1,444 & - \\
\hline EBONYI & 577,216 & 1,206 & $\overline{4}$ \\
\hline EDO & 898,084 & 1,879 & 118 \\
\hline EKITI & 964,179 & 903 & 126 \\
\hline ENUGU & $1,064,893$ & 812 & 99 \\
\hline GOMBE & 527,230 & 1,043 & 65 \\
\hline IMO & $1,296,386$ & 1,259 & 135 \\
\hline JIGAWA & 820,001 & 1,022 & 75 \\
\hline KADUNA & $1,635,453$ & 2,712 & 170 \\
\hline $\begin{array}{l}\text { KANO (Targeted } \\
\text { state) }\end{array}$ & $1,794,358$ & 7,790 & 496 \\
\hline KATSINA & $1,216,604$ & 1,256 & 99 \\
\hline KEBBI & 692,104 & 898 & 91 \\
\hline KOGI & 967,431 & 827 & 17 \\
\hline KWARA & 717,909 & 164 & 62 \\
\hline $\begin{array}{l}\text { LAGOS } \\
\text { (Targeted state) }\end{array}$ & $3,224,324$ & 11,044 & 619 \\
\hline NASARAWA & 382,086 & 1,098 & 22 \\
\hline NIGER & 977,240 & 1,258 & 100 \\
\hline OGUN & $1,165,848$ & 1,690 & $\overline{104}$ \\
\hline ONDO & $1,026,770$ & 1,805 & 194 \\
\hline OSUN & $1,356,174$ & 2,247 & 25 \\
\hline OYO & $1,864,954$ & 7,468 & 519 \\
\hline
\end{tabular}




\begin{tabular}{|l|r|r|r|}
\hline PLATEAU & 786,504 & 2,070 & 110 \\
\hline RIVERS & $1,749,911$ & 2,981 & 41 \\
\hline SOKOTO & 700,106 & 631 & 210 \\
\hline TARABA & 513,973 & 891 & 69 \\
\hline ZAMFARA & 722,360 & 577 & 16 \\
\hline FCT & 482,365 & 2,244 & 446 \\
\hline Total & $\mathbf{3 6 , 9 9 4 , 5 7 8}$ & $\mathbf{6 8 , 1 6 8}$ & $\mathbf{4 , 6 7 0}$ \\
\hline Grand total & $\mathbf{3 7 , 0 6 7 , 4 1 6}$ &
\end{tabular}

Source: National Bureau of Statistics Report (2016)

Table 4.1 above shows the numbers of micro, small and medium enterprises in each of the thirty six (36) states of the Federal Republic of Nigeria as well as the Federal Capital Territory (FCT). The study focused on three states, namely: Anambra, Kano and Lagos States.

\section{Table 4.2 Regression Result from Stata 14 (Dependent variable- PERF)}

\begin{tabular}{|l|l|l|l|}
\hline Variable(s) & Coefficient & T-statistics & P-Value \\
\hline C & 1.7876234 & 19.39 & 0.000 \\
\hline $\begin{array}{l}\text { Competitive } \\
\text { intelligence }\end{array}$ & .2201324 & 17.39 & 0.000 \\
\hline Social network & .1902673 & 9.06 & 0.000 \\
\hline Innovation & .1203452 & 5.05 & 0.001 \\
\hline Collaboration & .0894753 & 3.42 & 0.153 \\
\hline F-Statistics =248.03 (0.0000) & & R-Square $=0.2613$ & Adj R-Square $=0.2501$ \\
\hline
\end{tabular}

Source: Authors computation from STATA 14

Table 4.2 above revealed that business ecosystem components have a combined effect on MSMEs performance (F-value $248.03 * 0.0000)$. However, while competitive intelligence, social network, innovation all have significant positive effect on MSMEs performance, collaboration do not have significant effect on MSMEs performance at $5 \%$ level of significant. The adjusted $\mathrm{R}^{2}$ revealed that business ecosystem accounts for $25 \%$ variation in MSMEs performance.

\section{CONCLUSIONS}

The study empirically examined the effect of business ecosystem (measured by competitive intelligence, social network, innovation and collaboration) on MSMEs performance (measured by revenue, market share and employees satisfaction). Using survey research design, the findings revealed that business ecosystem components have a combined effect on MSMEs performance (Fvalue $248.03 * 0.0000$ ). However, while competitive intelligence, social network, innovation all have significant positive effect on MSMEs performance, collaboration do not have significant effect on MSMEs performance at $5 \%$ level of significant, with t-value of $17.39 * 0.000,9.06 * 0.000$, $5.05 * 0.001$ and $3.42 * 0.153$ respectively. The adjusted $\mathrm{R}^{2}$ revealed that business eco system accounts for $25 \%$ variation in MSMEs performance. This is inconsistent with the study by Paula \& Luís (2017) who carried out a meta-analysis on collaborative business ecosystem and firms' performance in Portugal and found that collaborative business ecosystem influences financial and non financial performance Indicators of firms. 
The inconsistency in findings might be as a result of the economic, political and socio-cultural differences between Nigeria and Portugal. However, business ecosystem components have positive and significant effect on MSMEs financial and non-financial performance, but collaboration, which is one of the component of business ecosystem does not significantly affect MSMEs financial and nonfinancial performance in Nigeria.

It can therefore be recommended that MSMEs seeking improved performance should enhance their competitive intelligence, social network, innovativeness, as this tends to improve their financial and non-financial performance.

\section{SUGGESTION FOR FURTHER STUDY}

The study faces potential limitations that may guide the directions for further research, further studies can be carried out on the effect of business eco system on large firms, the firms can equally be considered using sectors of the economy, like financial service sector, manufacturing sector, and agricultural sector, among others. Furthermore, future studies can employ interview as the method of data collection, as it tends to provide more information.

\section{REFERENCES}

Akanji, O.O. (2006). Micro finance as a tool for poverty reduction. Central Bank of Nigeria

Amit, A., Gloster, A., \& Muller, A. (1993). Challenges to theory and development in entrepreneurship and Policies. ( $2^{\text {nd }}$ ed). Harlow: FT. Prentice Hall.

Baghbadorani, M., \& Harandi, A. (2012). A conceptual model for business ecosystem and implications for the future, Research Gate Publication, 52 (17).

Balogun, O. L., Yusuf, S.A., \& Oloniniyi, M.T. (2017). Effects of social network on production output of maize farmers in Kwara State, Nigeria. Global Advanced Research Journal of Agricultural Science, 6(2)

Barnea, A., (2010). Intelligence failures: Competitive intelligence and strategic surprises. Competitive Intelligence Magazine, 13(3), July/ September.

Barney, T., Pan, Shan L., Lu, X., \& Huang, L. (2009). Leveraging digital business ecosystems for enterprise agility: The tri-logic development strategy of alibaba.com

Blanch, F., Oswald, D., \& Stutzer, A. (2001). Latent entrepreneurship across nations, European Economic Review, 45 (4-6), 680-91.

Clausen, T. H. (2006). Who identifies and exploits entrepreneurial opportunities? Centre for Technology, Innovation and Culture, University of Oslo. Retrieved from www.ccsr.ac.uk/method/festival/.../paper Tommy Clausen pdf.

Coleman, J. S. (1990). Foundations of social theory. Massachusetts, Cambridge: University Press.

Creswell, J.W. (2014). Research design: Qualitative and quantitative approaches. Thousand OAK, CA: Sage.

David, J. T. (2007). Explicating dynamic capabilities: the nature and microfoundations of (sustainable) enterprise performance, Strategic Management Journal, 28(13), 19-31

Drucker, P.F. (1954). Innovation and entrepreneurship practice and principles. London: William Heinemann LTD.

European Commission Discussion Paper (2013). Bruxelles. Retrieved from http://www.digitalecosyst em.org/html/repository/dbe_discussionpaper.pdf

Ebitu, E., Basil, G., \& Ufot, J. A. (2016). An appraisal of Nigeria's micro, small and medium enterprises (MSMEs): Growth, challenges and prospects. International Journal of Small Business and Entrepreneurship Research, 4(4)

Ekpe, I., \& Norsiah, M. (2015). Social Networks and Women Micro-Enterprise Performance: A Conceptual Framework, Mediterranean Journal of Social Sciences, 6(4) 
Eze, B.U., Worimegbe, P.M., \& Kolawole, O.O. (2016). The causal relationship between short-term finance and micro, small and medium scale enterprises survival in Nigeria. Crawford journal of business and social sciences, $6(2)$.

Gilad, B. (2008). The future of competitive intelligence: Contest for the profession's soul. Competitive Intelligence Magazine, 11 (5), 21-25

Iansiti, M., \& Levien, R. (2004). Creating value in your business ecosystem. Harvard Business Review, March 2004.

Ibrahim, S., \& Lloyd, C. (2011). The association between non-financial performance measures in executive compensation contracts and earnings management. Journal of Accounting and Public Policy, 30(3), 256-274.

Kaplan, R. S., \& Norton, D.P. (1996) Using the Balanced Scorecard as a Strategic Management System, Harvard Business Review (January-February), 75-85.

Kim, S. M., \& Sherraden, M. (2014). The impact of gender and social networks on microenterprise business performance. Journal of Sociology \& Social Welfare , XLI(3), 49-69.

Kotler, P. (2010). Marketing Management, Analysis, Planning, Implementation and Control. USA: Prentice-Hall.

Kuzilwa, J. (2005). The role of credit for small business success: A study of the national entrepreneurship development fund in Tanzania. The Journal of Entrepreneurship, 14(2), 131161.

Moore, J. F. (1993). Predators and prey: A new ecology of competition. Harvard Business Review.Available at http://hvrd.me/QPp06g.

Muller, A., Amit, A., \& Gloster, A. (1993). Challenges to theory and development in entrepreneurship research. Journal of Management Studies, 30(5), 815-825.

National Bureau of Statistics (2016). Micro, small and medium enterprises statistical data.

Ojo, O. (2009). Impact of microfinance on entrepreneurial development: The case of Nigeria. Doctoral desertation, University of Bucharest, Romania.

Paula, G., \& Luís, M. (2017). Performance indicators for collaborative business ecosystems Literature review and trends. Technological Forecasting and Social Change, 116(1).

Portes, A. (1998). Social networks: Its origins and applications in modern sociology. Annual Review of Sociology, 24(1), 1-24.

Oladimeji, M.S (2017). Relationship between entrepreneurship skill, strategic thinking and business ecosystem in Nigerian. Lasu Conference of Management Science, May, 2017.

Schumpeter, J. A. (1934). The Theory of Economic Development, Harvard University Press, Cambridge.

Watts, R. L., \& Zimmerman, J. L. (1986). Positive accounting theory, Englewood Cliffs, NJ: Prentice-Hall.

Yamane, T. (1967). Statistics: An introductory analysis, $2^{\text {nd }}$ edition, New York: Harper and Row. 